\title{
Peculiarities of developing professional competencies of commodity trading experts in construction
}

\author{
P. V. Zakharchenko, O. M. Gavrysh, O. P. Yudicheva \\ Kyiv National University of Construction and Architecture, Kyiv, Ukraine \\ Corresponding author. E-mail: tkd362@ukr.net
}

Paper received 09.11.18; Revised 13.11.18; Accepted for publication 15.11.18.

\section{https://doi.org/10.31174/SEND-HS2018-184VI30-16}

\begin{abstract}
The article considers modern approaches and possibilities of using a competency-based approach for training commodity specialists for construction area. A brief description of the pedagogical research in Ukraine which is devoted to the implementation of a competency-based approach during study has been given. The key professional competencies required for commodity trading experts in construction have been formulated and substantiated. The main directions for expanding and deepening of professional competencies of the commodity specialists who are trained by higher educational establishments of Ukraine have been outlined.

Keywords: competency, competency-based approach, commodity research, commodity trading experts, construction.
\end{abstract}

Introduction. The National Strategy of Education Development in Ukraine for the period up to 2021 [1] states that the key task of education in the XXI century is the development of thinking oriented towards the future. This document reasons that the modern labor market requires from a graduate not only to have profound theoretical knowledge, but also the ability to apply it independently in non-standard, constantly changing life situations, the transition from a knowledge society to the society of lifecompetent citizens. One of the strategic directions of state policy in the field of education is to modernize its structure, content and its organization on the grounds of a competency-based approach.

A brief overview of publications on the topic. A significant amount of pedagogical research in Ukraine is devoted to the implementation of a competency-based approach in study, as well as to the development of such a system of diagnostic tools, which will be used not only to evaluate the knowledge and skills of a graduate of a higher school, but to assess his/her competence and competencies. In their works, scientists pay considerable attention to the deep essence of this approach.

The author of the paper [2] believes that in modern science there is a steady tendency not only to establish the concept of "a competency-based approach", but also to understand its essence, since the implementation of this approach is based on the awareness that social progress doesn't depend only on economic growth - it is also dependant on the level of personal development. The author concludes about the necessity of the transition from the qualification that a specialist acquires once and for all to the competency that allows to change professional activities due to social and economic changes, dynamics of the labor market, and the concept of the Bologna process. In the work [3] the emphasis is placed on the fact that a competency-based approach determines the result-based education. Competence is the goal of educational activity, and competency is a measure, degree, completeness of its achievement by a specific educational actor. The ultimate result of learning is the development of people's competencies, the transfer of emphasis from the level of knowledge of the people involved in study to their ability to apply the information to solve practical problems.

The author of the paper [4] emphasizes that competency should not be opposed to knowledge, abilities or skills. The concept of competency is wider than the concepts mentioned above. It contains the outcomes of learning (knowledge and skills), a system of values, habits, etc.; Competencies are formed in the process of learning, not only at secondary and higher schools; they are also influenced by the family, friends, work, politics, religion, culture, etc. The paper [5] states that the existing standards of higher education are based on the qualification model of a specialist. As a result of this, a knowledge component dominates in the standards; these standards can't assess the quality of education on the basis of such indicators as readiness of graduates for future professional activities and the level of professional motivation.

The program competencies are classified into general and special (professional, subject-oriented) ones. General competencies include competencies that characterize knowledge, abilities, and skills that are universal by nature and are acquired within a particular educational program. Professional competencies are the key competencies that are used to get any professional degree of training and are directly related to the special knowledge necessary to carry out the core professional activities.

Commodity trading experts have played and play a key part in organizing trade in non-food and food products. They have always had an important mission - to provide consumers with high-quality and safe goods in the fullest and widest assortment. At present, there is a significant expansion of the area for the use of commodity specialists in Ukraine; the considerable attention is paid to the list of key professional competencies that future professionals acquire during their training.

Taking into account the requirements of the present time, it is justified to use a competency-based approach in the educational process of higher schools of the commodity profile in the context of training specialists for trade. The authors of the paper [6] state that the introduction of a competency-based approach in the system of training specialists can solve urgent issues that exist today in the field of national higher education and are related to training of modern commodity specialists. According to the authors, this will allow the following:

- to improve the quality of training specialists of this profile and to extend the level of their professional competencies to the needs of modern markets;

- to develop a more thorough theoretical and methodological approach to assortment development, quality and safety of non-food products and radical reorganization of 
its own educational and methodological base of training commodity specialists at higher schools on this basis.

Table 1. Characteristics of key professional competencies of a commodity expert in construction

\begin{tabular}{|l|l|l|l}
\hline$№$ & Name and characteristics of competency \\
\hline
\end{tabular}

Knowledge of the basic terms and concepts related to the

1. technology of manufacturing, purpose, assortment, quality assessment of construction products

2. Knowledge of classification, properties and areas of 2. application of construction products

3. Ability to distinguish and provide a commodity-specific 3. characteristic of basic properties of construction products

Ability to distinguish and characterize the composition

4. of construction products, peculiarities of their manufacturing and application

5. Knowledge of the main factors influencing quality and 5. safety of construction products

Ability to carry out an expert research on quantity and

6. quality of construction products with drawing a substantiated conclusion

7. Knowledge of the causes of defects in construction

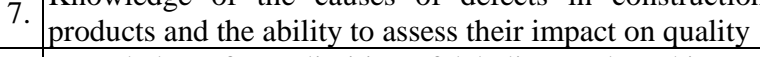

8. Knowledge of peculiarities of labeling and packing of

8. $\begin{aligned} & \text { construction goods made in Ukraine and abroad } \\ & \text { con }\end{aligned}$

9. Knowledge of the peculiarities of the use of construction goods

10. Knowledge of the current normative documentation on 10. construction goods and the ability to use it

11. Ability to conduct sampling and to assess quality and

11. safety of construction products

The work [7] is devoted to study of modern approaches and possibilities of using a competency-based method for training commodity experts at higher educational establishments of Ukraine. The conclusions on the urgent need for conducting in-depth commodity research of the issues related to the formation and evaluation of key professional competencies of commodity specialists have been made. The authors of the paper [8] have substantiated the content and the list of key professional competencies of commodity specialists in trade, as well as have paid attention to the way these competencies comply with the requirements of the modern domestic market. The peculiarities of developing professional competencies of com- modity experts in knitting have been considered in the work [9]. This work gives a number of reasons determining the necessity of using a competency-based approach and the contextual form of training for preparing commodity specialists.

market or supermarket departments, and trade firms. Under these conditions, the need for commodity specialists with certain key professional competencies is undeniably substantiated and very important.

In the work [10], the peculiarities of the professional activity of commodity trading experts in construction are generalized. In accordance with the specifics of the activity and the object this activity is aimed at, some basic professional competencies of Bachelors of the commodity profile have been defined; their practical activity will be aimed at the organization of trade in construction products.

The purpose of the article is to reveal the aspects of a competency-based approach in education as the focus area of its modernization and to analyze the peculiarities of developing professional competencies during training commodity trading experts in construction.

Materials and methods System analysis, generalization of data comparison from the research issue based on the study of scientific pedagogical and methodological literature, pedagogical experiment.

Results and discussion. Construction products are a special group of non-food products whose range is constantly expanding and renewed due to the use of modern raw materials and innovative production technologies. This group of goods is aimed not only at an individual consumer, but also at special construction companies and firms involved in construction, arrangement, repair of various premises. Therefore, construction products are often sold through a number of specialized stores, hyper After all, only professionals can skillfully and thoughtfully form a range of types and subtypes of construction products, understand all the nuances of labeling, evaluate quality, focus on safety of certain goods and provide advice about their use and storage conditions to consumers. Table 1 outlines the main key professional competencies of commodity specialists whose future professional activity will be related to trade in construction products.

Table 2. Characteristics of competencies required for conducting expert studies and determining quality and safety of construction products

\begin{tabular}{|c|c|c|c|}
\hline \multirow[t]{2}{*}{ Name of competency } & \multicolumn{3}{|c|}{ Degree of a specialist's training } \\
\hline & Bachelor & Master & Doctor of Philosophy \\
\hline $\begin{array}{l}\text { Knowledge of basic terms and } \\
\text { concepts related to the technolo- } \\
\text { gy of manufacturing, purpose, } \\
\text { assortment, assessment of quali- } \\
\text { ty of construction products }\end{array}$ & $\begin{array}{l}\text { Knowledge of } \\
\text { basic terms and } \\
\text { concepts }\end{array}$ & $\begin{array}{l}\text { Full understanding of the essence of basic } \\
\text { terms and concepts }\end{array}$ & $\begin{array}{l}\text { Complete understanding of the } \\
\text { deep essence of basic terms and } \\
\text { concepts, their logical connection } \\
\text { and comparison at the domestic, } \\
\text { European and world level }\end{array}$ \\
\hline $\begin{array}{l}\text { Ability to conduct sampling and } \\
\text { to assess quality and safety of } \\
\text { construction products }\end{array}$ & $\begin{array}{l}\text { Ability to carry } \\
\text { out sampling } \\
\text { and organolep- } \\
\text { tic quality as- } \\
\text { sessment }\end{array}$ & $\begin{array}{l}\text { Ability to carry out sampling, quality } \\
\text { assessment using organoleptic and certain } \\
\text { physical and chemical indicators }\end{array}$ & $\begin{array}{l}\text { Ability to conduct sampling, } \\
\text { quality assessment using organo- } \\
\text { leptic, physical and chemical } \\
\text { indicators as well as safety indica- } \\
\text { tors with the help of modern } \\
\text { equipment }\end{array}$ \\
\hline $\begin{array}{l}\text { Ability to assess the composi- } \\
\text { tion of construction products }\end{array}$ & \begin{tabular}{|l} 
By labeling, \\
external features
\end{tabular} & With the help of chemical methods & $\begin{array}{l}\text { With the help of physical and } \\
\text { chemical methods }\end{array}$ \\
\hline $\begin{array}{l}\text { Ability to apply construction } \\
\text { products in buildings and car- } \\
\text { casses }\end{array}$ & $\begin{array}{l}\text { In accordance } \\
\text { with the instruc- } \\
\text { tions }\end{array}$ & $\begin{array}{l}\text { In accordance with the instructions, taking } \\
\text { into account the features of buildings and } \\
\text { carcasses, as well as external and internal } \\
\text { negative environmental factors }\end{array}$ & $\begin{array}{l}\text { Analysis of domestic and world } \\
\text { experience. Providing scientifical- } \\
\text { ly substantiated recommendations } \\
\text { for application }\end{array}$ \\
\hline
\end{tabular}


It is clear that the trade sector needs commodity experts of different degrees of professional training - Bachelors, Masters and Doctors of Philosophy. Their competencies are similar while differing in their depth, which is due to the content of training at higher schools (Table 2).

The list of competencies necessary for assessment of the quality and safety level, the structure of assortment, properties of construction products requires further substantiation, refinement and specification, taking into account all peculiarities of training commodity trading experts in construction. These competencies must be reconsidered and compiled with the needs and demands of the product market in order to form a result-oriented specialist.

Competency in a certain field is a combination of relevant knowledge and skills that allow a reasonable assessment of a particular area and effective performance in it. But one can draw conclusions objectively, reasonably and comprehensively only provided that a certain area is maximally studied both at the domestic and world level. To prepare a modern commodity trading expert in construction, who will quickly respond to changes in the market of building technologies and goods, have a complete picture of manufacturers and suppliers and assess quality of their products is impossible without the experience gained by specialists of similar area in the leading countries worldwide.

Graduates of higher educational establishments of the commodity profile can extend their professional competencies during seminars, short-term lecture courses on specific educational disciplines at the universities with similar specialties all over the world. This process can be facilitated by bilateral cooperation agreements and exchange of students. The combination of professional competencies acquired in home educational institutions and obtained while studying abroad can lead to a positive synergistic effect resulting in the formation of a highly skilled and highly-demanded specialist.

However, only the student fluent in foreign languages, especially in the language for specific purpose, can go that way. The correct and unambiguous understanding of the terms and concepts when it comes to building materials, products and structures will contribute to the proper application of the gained key professional competencies by a commodity trading expert while fulfilling basic professional tasks. In this case, we can talk about the close relationship of general and professional competencies.

Conclusions. Nowadays it is necessary to work on the formulation, substantiation and specification of professional competencies of commodity trading experts in construction, to comply these competencies with the needs of the modern market of construction goods, which undergoes constant changes. To expand the range of key professional competencies of future commodity experts students should practice the experience of mastering certain special disciplines at foreign higher schools with related specialties. The prerequisite for commodity trading experts in construction to acquire professional competencies is a good command of a foreign language, which is very important for a person's mobility and mastering best practices.

\section{ЛИТЕРАТУРА}

1. Про національну стратегію розвитку освіти в Україні на період до 2021 року: Указ Президента України від 25.06.2013 № 344/2013 // База даних «Законодавство України» / BP України. http://zakon3.rada.gov.ua/laws/show/344/2013.

2. Часникова О. В. Компетентнісний підхід в освіті як основа іii реформування. URL: https://www.narodnaosvita.kiev.ua/?page_id=2607.

3. Гулай О. І. Компетентнісний підхід як основа нової парадигми освіти // Педагогічна наука. Вісник Національної академії Державної прикордонної служби України, 2009. 2, C. 41-51.

4. Ящук С. Компетентнісний підхід у підготовці магістрів технологічної освіти // Збірник наукових праць Уманського державного педагогічного університету, 2012. 2, С. 341-348.

5. Фурдуй С.Б. Компетентнісний підхід у вищій школі в Україні: розробка та впровадження ідей при підготовці фахівців соціономічної сфери // Молодий вчений, 2017. 3 (43), C. 485-489.

6. Пушкар Г. О., Семак Б. Д. Особливості використання компетентнісного підходу у ЗВО сфери вітчизняної торгівлі // Актуальні проблеми теорії і практики експертизи товарів: матеріали V Міжнародної науково-практичної інтернет-конференції (м. Полтава, 20-22 березня 2018 р.).

Полтава: ПУЕТ, 2018, С. 357-360.

7. Галик І. С., Семак Б. Д. Компетентнісний підхід - основа професійної підготовки товарознавців у вищих навчальних закладах // Вісник Львівського торговельноекономічного університету, 2017. 18, С.16-21.

8. Галик І. С., Ніколайчук Л. Г., Семак Б. Д. Експертиза професійних компетентностей товарознавців сфери торгівлі // Актуальні проблеми теорії і практики експертизи товарів: матеріали V Міжнародної науково-практичної інтернет-конференції (м. Полтава, 20-22 березня 2018 р.). Полтава: ПУЕТ, 2018, С. 329-332.

9. Пахолюк О. В., Галик І. С., Семак Б. Д. Формулювання професійних компетентностей товарознавців торговельного трикотажного підприємства // Актуальні проблеми теорії і практики експертизи товарів: матеріали V Міжнародної науково-практичної інтернет-конференції (м. Полтава, 20-22 березня 2018 р.). Полтава: ПУЕТ, 2018, С. $350-354$

10. Захарченко П. В., Юдічева О. П., Алавердян Л. М. Компетентнісно-орієнтований підхід до підготовки фахівців 3 товарознавства та комерційної діяльності в будівництві // Мережевий бізнес: становлення, проблеми, інновації: матеріали VIII Міжнародної науково-практичної Інтернет конференції (м. Полтава, 19-20 квітня 2018 р.). Полтава: ПУЕТ, 2018, С. 44-46.

\section{REFERENCES}

1. On the National Strategy for the Development of Education in Ukraine until 2021: Decree of the President of Ukraine dated June 25, 2013 № 344/2013 // Legistation Ukraine / Verkhovna Rada of Ukraine. URL: http://zakon3.rada.gov.ua/laws/show/344/2013.

2. Chasnykova, O. V. Competency approach in education as the basis of its reform. URL: https://www.narodnaosvita.kiev.ua/?page_id=2607.

3. Hulay, O. I.Competency approach as the basis of a new education paradigm // Pedagogical sciences. Bulletin of the National Academy of the State Border Guard Service of Ukraine, 2009. 2. P. 41-51.

4. Yashchuk, S. Competency approach in preparation of masters of technological education // Collection of scientific works of Uman State Pedagogical University. 2012. 2. P. 341-348.

5. Furdui, S. B. Competence Approach in Higher School in 
Ukraine: Development and Implementation of Ideas in the Training of Specialists in the Sphere of Socionomics // Young Scientist, 2017. 3 (43). P. 485-489.

6. Pushkar, H. O., Semak, B. D. Features of the use of a competent approach in the area of domestic trade // Urgent Issues of the Theory and Practice of Commodity Expertise: Conference papers 5th International Scientific and Practical Internet Conference (Poltava, March 20-22, 2018.). Poltava: PUET, 2018. P. 357-360.

7. Galyk, I. S., Semak, B. D. Competence Approach - the Basis of Professional Training of Commodity Research Specialists in Higher Educational Institutions // Visnyk of Lviv Trade and Economic University, 2017. 18. P.16-21.

8. Galyk, I. S., Nikolaychuk, L. H., Semak, B. D. Expertise of professional competencies of merchants in the sphere of trade // Urgent Issues of the Theory and Practice of Commodity Expertise: Conference papers 5th International Scientific and
Practical Internet Conference (Poltava, March 20-22, 2018). Poltava: PUET, 2018. P. 329-332.

9. Pakholyuk, O. V., Galyk, I. S., Semak, B. D. Formulation of professional competencies of commodity traders of a commercial knitting enterprise // Urgent Issues of the Theory and Practice of Commodity Expertise: Conference papers 5th International Scientific and Practical Internet Conference (Poltava, March 20-22, 2018.). Poltava: PUET, 2018. P. 350-354.

10. Zakharchenko, P. V., Yudicheva, O. P., Alaverdyan L. M. Competency-oriented approach to the training of specialists in commodity research and commercial activities in construction // Network Business: Becoming, Problems, Innovations: Conference papers 8th International Scientific and Practical Internet Conference (Poltava, April 19-20, 2018). Poltava: PUET, 2018. P. 44-46. 